\title{
Behavioural Economics and House Prices: A Literature Review
}

\author{
Richard Whittle \\ Dept. of Accounting, Finance and Economics, Manchester Metropolitan University \\ NBS Building, All Saints, Manchester, M15 6BH, UK \\ Tel: 44-161-247-3752Ｅ-mail: r.whittle@mmu.ac.uk
}

Thomas Davies

Dept. of Accounting, Finance and Economics, Manchester Metropolitan University NBS Building, All Saints, Manchester, M15 6BH, UK E-mail: daviest7@hotmail.com

\section{Matthew Gobey}

Dept. of Accounting, Finance and Economics, Manchester Metropolitan University

NBS Building, All Saints, Manchester, M15 6BH, UK

Tel: 44-161-247-3872Ｅ-mail:m.gobey@mmu.ac.uk

\section{John Simister (Corresponding author)}

Dept. of Accounting, Finance and Economics, Manchester Metropolitan University NBS Building, All Saints, Manchester, M15 6BH, UK Tel: 44-161-247-3899Ｅ-mail: j.g.simister@mmu.ac.uk

Received: September 3, 2014 Accepted: October 16, 2014 Published: November 3, 2014 doi:10.5296/bmh.v2i2.6262ＵRL: http://dx.doi.org/10.5296/bmh.v2i2.6262 


\section{Abstract}

This paper investigates previous research, to examine ways in which behavioural economics helps us to understand how house prices are determined. In several respects, behavioural economics seems to be an improvement over neoclassical economics, regarding variations and trends in house prices. This paper analyses theoretical and empirical evidence investigating topics such as loss aversion, house price bubbles, and herd behaviour. Historical perspectives (including the 2007/8 global financial crisis) are included, as well as differences between countries.

Keywords: neoclassical economics, behavioural economics, house prices 


\section{Introduction}

Many economists claim that until recently, neoclassical economics has been the standard way for economists to explain house price changes; Marsh \& Gibb (2011) found this has been the dominant approach throughout the history of economics as a subject. This suggests there has been little influence of psychology on economics. However, Earl (2005) disagrees, claiming the convergence of psychology and economics dates back to Adam Smith (1759).

Behavioural economics is a partnership between economics and psychology. Many economists such as Akerlof \& Shiller (2009) claim that economic analysis should not be restricted to neoclassical economics, but should incorporate insights from behavioural economics. This paper reports a number of theories which could be considered to belong to 'behavioural economics'. It is beyond the scope of this paper to provide an exhaustive list of alternative theories: there are too many publications on house prices for them all to be analysed in one paper. This paper aims to give an overview of behavioural economics insights relevant to house prices; it also mentions other topics, such as stock markets.

Housing markets are unlike any other market (Smith, 2011b). The heterogeneity of the housing market, according to Meen (1996), makes it difficult to categorise: each house is different, and housing markets contain many varying factors, where no two houses are identical (taking into account the interior and exterior of the property). Cho (1996) provides evidence of the difficulty in measuring a housing market, due to the heterogeneity of attributes that define particular houses. Housing markets are imperfect (Boelhouwer, 2011): there are many reasons for this, including recessions causing delayed movements in house prices and stagnation. The UK Housing market, according to Miles (2004), is widely considered to be a major transmission mechanism for volatility in the UK economy as a whole.

This paper begins by outlining neoclassical economics and behavioural economics; it then introduces some key ideas from behavioural economics which are relevant to house prices, grouping related ideas in sections. It concludes with a comment on the future of neoclassical economics.

\section{Neoclassical Economics and Behavioural Economics}

Neoclassical economic perspectives on how individuals interact have dominated the academic history of the field and how it has influenced policy makers. Neoclassical models have historically assumed, explicitly and implicitly, that we are 'rational' agents. This means we act in ways which maximise our expected 'utility' (happiness), based on the full set of information available to us. When making decisions we reflect on this information to ensure our choice to enter a market truly reflects our needs, as we perceive them. We are all capable of this.

The 'First Fundamental Theorem of Welfare Economics' holds that if there is a full set of competitive thick markets for current and future needs, then a decentralized set of markets will maximise utility across society, for a given initial distribution of skills and resources ('thick markets' means many buyers and many sellers). In housing markets, the 
heterogeneous nature of houses in terms of size, condition, orientation, location, modifications, attachment etc., make this a challenging condition. Moreover, these markets need to hold in all states of nature (i.e. all risks can be offset).

If the price of housing reflects its value as an asset as well as a source of shelter (home) we could also address price formation by employing the allied 'Efficient Markets Hypothesis', which is associated with Adam Smith (1759). This hypothesis not only holds that we are utility maximizing individuals, but also rational in our price formation. Updating our preference rankings as new information becomes available and hence our willingness to obtain or hold an asset. That is we form rational (price) expectations, which on a population basis are not biased, that is they are (once averaged) correct and preclude systematic excessive returns. This implies that stock markets work effectively, incorporating all relevant information, and producing an appropriate allocation of resources - for example, ensuring that investment is channelled into firms which can best use resources to produce cheaper or better products. Neoclassical economists argue that changes in interest rates have profound effects on adjustable-rate mortgages (Madsen, 2012); mathematical calculations regarding effects of interest-rates on mortgage payments seem reliable, but modelling human behaviour is much less precise.

There is now increasing criticism of neoclassical economics. Many writers criticise the assumption that people act as rational agents, including Tversky \& Kahnemann (1974) and Kahnemann \& Tversky (1979). Daniel et al. (1998) claim asset-pricing models based on rationality (i.e. neoclassical economic models) cannot explain patterns that are observed regularly by economists. One departure from neoclassical economics is 'bounded rationality', which suggests each person has a limited ability to obtain and interpret information. Conlisk (1996) suggests economists have more success in explaining actions of real world agents if they assume bounded rationality, rather than the neoclassical economics assumption of completely rational behaviour by each agent.

Watkins \& McMaster (2011) report difficulties of conventional economic modelling to adequately explain house-price changes, and the choice processes underlying house-price changes. Many economists such as Shiller (2005), Akerlof \& Shiller (2009), and Stiglitz (2010) claim there is a need to reform the way economic modelling is approached - with more emphasis on the non-conformity of human actions. This suggests potential for behavioural economics to provide useful tools to economists. Behavioural economists claim we can understand economic behaviour better, if we include insights from psychology. Fudenburg (2006) and Della Vigna (2009) think psychology, in harmony with economics, can explain behavioural anomalies such as asset bubbles in property markets and stock markets.

Earl (2005) found there was limited acceptance that psychology can offer helpful advice to economic policy decisions. Behavioural economists were criticised, because early tests were mostly based in laboratories; it was claimed that laboratory results are inapplicable to people in their natural working environment (Smith, 2011b). Some writers argued that behavioural economics has not enabled any further understanding into the dynamics of the housing 
market; and that there is not enough precision in behavioural explanations, using subjective non-empirical approaches based on the psychology of human interaction (Smith, 2011b). Northcraft \& Neale (1987) disagreed, and showed that decisional biases and heuristics found in the laboratory are applicable to the real world.

Behavioural implications on the housing market, and ways in which humanistic biases and cognitive errors affect and ultimately distort asset prices, received limited coverage until the financial crisis in 2008: behavioural economics was seen as a minority view, until the global financial crisis incorporated it into mainstream ideas (Marsh \& Gibb, 2011). Since then, the spotlight refocused on economic explanations outside the mould of rational economic thinking (Akerlof \& Shiller 2009), and the effects non-rational thinking had on lending in housing markets. Watkins \& McMaster (2011) claim there is now a breakdown in reliance on mainstream economic analysis. Akerlof \& Shiller (2009) provide arguments for behavioural insights in housing markets. Smith (2011a) asserts behavioural economics could have a role in concert with a wider range of disciplines in significantly enlarging our understanding of economic behaviour. However, to date she argues the research, in terms of housing and financial markets, has been empirically and methodologically limited. If behavioural economics is to provide deeper understandings of economic behaviour it needs to incorporate a more fundamental consideration of sociological process. Currently, it replaces the machine-like rational person with a limited naïve caricature of individuals. Behavioural economics is still very emphatically a developing field; Iroham et al. (2014) claims behavioural insights are helpful to assess real estate prices, but they acknowledge the need for further research.

\section{House Price Bubbles}

The term 'bubble' describes a period when the price of an asset departs from the true value of that asset. The Efficient Market Hypothesis (part of neoclassical economics) suggests bubbles cannot exist: supply \& demand in stock markets automatically correct the price of each asset, to reflect its true value - taking account of factors such as risk. In a perfectly rational environment, Diba \& Grossman $(1987 ; 1988)$ state a bubble could only exist if the planning horizon of the economic agent is infinite. Stiglitz (1990) argued that if individuals are rational, they would foresee the date when the bubble would burst, and sell the asset before that lowering prices; this fall in the asset price would also be foreseen; hence bubbles would not exist. Scherbina \& Schlusche (2012) claim that with high levels of substitutability in stock markets, a bubble is incompatible with rational behaviour. In housing markets, as soon as prices become too high, it becomes rational to relocate elsewhere to purchase cheaper property in a different area of the country; regional land bubbles cannot exist if perfectly rational actors invest in housing markets. However, there is evidence that regional bubbles do exist, such as in parts of rural Cheshire and London (Scherbina \& Schlusche, 2012). In many nations (including the UK), the after-effects of the bursting of the house-price bubble led many people into a 'Mobility Trap', in which they could not relocate to jobs more favourable to their skill set (Stephens, 2012). This suggests that, if bubbles occur, we must reject the neoclassical assumption that every person is rational. 
Many writers consider the global financial crisis which occurred around 2008 to have been caused by 'bubbles' in house prices - especially in the USA subprime housing market. But this was not the first house-price bubble: housing booms happened across the globe in the decades before 2007. Real house prices also rose and fell dramatically in the 1970s and 1980s (Levin \& Wright, 1997; McCord et al., 2011). Since the 1990s, UK house prices doubled in real terms, and the Spanish housing market experienced similarly large rises in the relative value of property (Niemietz, 2012).

House-price bubbles are important: they affect the economic outlook of some European nations today. Brocker \& Hanes (2014) claim bursting of housing bubbles have more effect on subsequent recovery of the economy than a stock market collapse; and that bank balance sheets have greater exposure to residential markets than to equity and derivative markets, causing negative effects on bank liquidity. The disruptive nature of the 2007/8 financial crisis and the reduced flow in the global financial systems has all been affected by falling confidence in the housing markets throughout the globe (Muellbauer \& Murphy, 1997; 2008).

The need for behavioural economics insights into the housing market was increased by the lack of understanding of the sub-prime lending crisis, which burst in 2007/8. Stephens \& Quilgars (2008) showed that it was not just the USA which had sub-prime lending: fears over UK housing were also apparent - Stephens \& Quilgars (2008) suggested UK institutions actively pursued sub-prime mortgages, to increase their asset bases and generate greater long-run profits. In UK, it was not just the English and Welsh housing market that was enveloped in a housing bubble: Northern Ireland experienced the largest gains in UK property prices, giving it the third highest average house price per area in 2007 in the UK however since the crash, Northern Ireland prices rapidly declined, and in 2010 had the lowest price per area in the UK (McCord et al., 2011).

\section{Herd Behaviour}

John Maynard Keynes used the term “Animal Spirits” of economic agents, to explain irrational exuberance or pessimism in an economy. This term has been more recently adapted and reinvented, as a way to explain many factors that are not explained by neoclassical economics. Some behavioural economists consider that humans often behave as a 'herd', as opposed to each person making their own decision about buying \& selling. Nakagawa et al. (2012) claimed that herd-like behaviour is rife in financial markets, where experience in the field is much greater than in housing markets. Morone \& Samanidou (2008) showed an individual making a decision is likely to override the private information they hold, to conform to a popular trend of thinking.

People often overestimate future price rises: among property investors, expectations of capital appreciation are unrealistic (Pompian, 2012; Shiller, 1996). Case \& Shiller (2003) asked people in various US cities "On average, how much do you expect the value of property prices to appreciate of the next each year?" Individuals expected a $38 \%$ price-rise in real terms, whereas the actual price-rise was only 5.7\%. Many people seem to believe that property prices will always rise (Case \& Shiller, 1989). 
Ackert et al. (2011) claim that a house price is based on future price expectations; many people partake in speculative housing transactions, such as during the later stages of Sub-Prime mortgage lending in the USA. Hence, housing demand is partly driven by biased price expectations (e.g. conviction based reasoning or money illusion) - when prices rise, demand is greater; whereas when prices fall, demand is lower. The reverse of what neoclassical economists assume. Scherbina \& Schlusche (2012) refer to 'feedback trading' a chartist view, assuming stock price changes are based on previous price changes (similar to the weak form of the Efficient Market Hypothesis), allowing unnatural growth above the fundamental value of an asset. These effectively create a Ponzi process (Minksy, 1977), causing a flood of money into the housing market - forcing up prices artificially. Clark et al. (2009) suggest the 2008 financial crisis was exacerbated by speculative transactions: the global housing market bubble was driven by emotion, rather than by sound investment decisions. Tsai et al. (2010) show that speculation leads to volatility in a housing market, causing greater fluctuations to UK house-prices; this suggests speculation is based on behavioural instincts.

Positive news tends to cause an increased demand for the commodity or stock traded that received the positive news; whereas price falls are to be expected when negative news is released. Shiller (2002) argues that the behaviour of news media intensifies asset price changes - bubbles were intensified by media interpretation of events such as the dotcom boom, where irrational investors could not see the downside risk whilst over-indulging in the philosophy that the dotcom boom was likely to continue indefinitely. Bhattacharya et al. (2009) applied the findings of Shiller (2002) to the dotcom crash, showing a disproportionate coverage of dotcom crashes, compared with collapsing prices of financial assets other than dotcom companies; this increased the effects of sensationalist news headlines.

\section{Amateurs and Experts}

Ackert et al. (2011) suggest housing bubbles are easily affected by inexperienced individuals and financially unsophisticated households. Hong (2007) suggests most households lack financial knowledge; for most individuals, a house purchase is their largest and most important financial transaction. Infrequent purchases in housing markets, and the fact that all prices are negotiated individually (rather than on a market system like the stock market), create inefficient housing markets. Most people in a housing transaction are inexperienced amateurs, with limited information about the market (Smith \& Smith, 2006). House-buyers fail to assimilate all information regarding their ability to repay, if the economic situation does not materialise as they expect (Ackert et al., 2011).

Arthur $(1991 ; 1993)$ tested the computational ability of individuals: they showed varying degrees of ability - and differing cognitive processing capacities; this seems to support the 'bounded rationality' view. Scheikman \& Xong (2003) show that many individual investors believe they have the ability to estimate correctly the price trend of a commodity. If such investors are correct, then they are better investors than other people; if they are incorrect, they are likely to make inappropriate investments, because they have too much confidence in their own ability to judge asset values. Whether those investors are correct or incorrect, their 
beliefs reject fundamental assumptions of neoclassical economics (that every person is equally effective in assessing prices). Behavioural biases affect the rise and expansion of bubbles, such as overconfidence from speculative perceptions of house price rises; and affect the correction of housing at the end of a bubble. When negotiating a selling price, the asking price - however erroneous - affects the buyer's judgement (Diaz \& Black, 1996). Individuals do not use sound economic valuations, and are tricked into valuations due to arbitrary reference points.

Northcraft \& Neale (1987) suggested that amateur investors are able to readily admit to biases, whereas experts (professional traders in housing markets) less likely to own up to flaws in estimations. Haigh \& List (2005) provide evidence that experienced traders exhibit greater behavioural anomalies than students. Bokhari \& Geltner (2011) report that experienced individuals are affected more (than inexperienced individuals) by loss aversion bias.

\section{Anchoring, Loss Aversion and Endowment Bias}

A key factor affecting house prices, and resetting of housing prices once a bubble bursts, is 'loss aversion' (Bokhari \& Geltner, 2011). This is where home owners are affected by reference points such as purchase price, and are unable to cope with selling their house at a loss. This derives from 'prospect theory' (Kahnemann \& Tversky, 1979), which claims economic agents do not treat a loss with equal measure to a gain. Perfectly rational sellers and buyers would ignore the initial buying price when assessing the current price; but Paraschiv \& Chenavaz (2011) found this is certainly not the case - the reference point of a house purchase has greater weighting than the current market price. A broadly similar approach is the 'disposition effect', where investors tend to be too willing to sell high-return assets, but too unwilling to sell loss-making assets: "investors are risk averse when in profit, risk loving when in loss” (DeWeaver \& Shannon, 2010: 18). One or both of these hypotheses(loss aversion, and disposition effect) may explain why we rarely see falls in house prices (Odean, 1994): since 2007, there have been widespread effects of price stickiness in housing markets, caused by anchoring to price reference points (Bokhari \& Geltner, 2011). Engelhardt (2003) provides evidence that loss aversion affects pricing of homes in a metropolitan housing market. Evidence from Paraschiv \& Chenavaz (2011) suggests that a house-price fall is less harmful than might otherwise be expected: irrational behaviour caused by loss aversion may limit the damage caused by (irrational) housing bubbles, hence house prices do not fall to an equilibrium level.

With low interest rates and little government intervention, there is sufficient demand to continually increase the price even after mortgage lenders consider the price to be over-valued (Whittle, 2013b). However, even if housing demand drops, homeowners often will not drop house prices because their perception based on (over) confidence of long-term future rises, anchoring to a reference point of previous perceived value or simple loss aversion, prevents them from lowering the price. For households which have no necessity to sell, the literature suggests that a house price bubble will plateau at a level based on a 
previous value, and remain there until either interest-rate movements or government intervention spark further demand.

The term 'money illusion' refers to a condition where most consumers think in nominal prices - rather than real prices (i.e. prices which have been adjusted for inflation). Akerlof \& Shiller (2009) and Madsen (2012) claim money illusion has significant effects. Home owners are unwilling to sell their property for a nominal loss; whereas they may be happy to sell at a nominal gain, even if it is a loss in real terms (Paraschiv \& Chenavaz, 2011). Genesove \& Mayer (2001) show sellers in housing markets aim to choose a selling price higher the market price, as a way to recoup nominal losses they face.

Another irrational behaviour incompatible with neoclassical economics is 'endowment bias', in which people place a higher value on an asset (such as a house) which they own themselves (Pompian, 2012; Kahneman, Knetsch \& Thaler, 1990). This may exacerbate housing bubbles, because of the disparity between renting and home ownership, in UK and USA for example. Marsh \& Gibb (2011) note that many people see renting as a waste of money; and consider home ownership as fundamental to their lifestyle (Whitehead \& Williams, 2011). This UK behaviour is different to continental Europe, where renting for long periods of time is more accepted. Many people buy a house partly to bequeath it to their offspring, or treat property as their own investment or potential retirement plan (Case \& Shiller, 2003); "bricks and mortar" is still seen as the most promising pension provision over a lifetime, as opposed to the normal route of saving followed by purchasing an annuity upon retirement (Jones et al., 2012). The switch from pension saving to property for retirement purposes may transform the housing market (Whittle, 2013a).

\section{Conclusion}

Behavioural instincts change the decision-making of economic agents in many different situations and environments, whether in a stock market environment or a housing market transaction. The literature discussed in this paper suggests cognitive biases have direct effects on the house-price decisions; these biases sometimes lead to a 'housing bubble'. This paper combines such biases into three types. The first type is 'herd behaviour', which implies a person's behaviour may be influenced by the group they are a member of. The second type is overconfidence, demonstrated by the dotcom bubble around 2000, as well as by the subprime housing market which preceded the 2007/8 global financial crisis; overconfidence is related to differences between 'amateurs' and 'experts'. The third type of bias examined in this paper is anchoring or loss aversion, and endowment bias. Bubbles can arise becausemany house sellers have no necessity to sell (if they consider house prices too low), and buyers want to buy due to a combination of societal, cultural, and herd-like pressures.

This paper outlines how behavioural economics uses insights from psychology, to produce explanations of human behaviour which seem more accurate than neoclassical economics. Readers may wonder if economists should now stop teaching neoclassical economics in universities. To answer this question, consider the impact of Albert Einstein's relativity theory on physics: experimental evidence showed many of Einstein's predictions are more accurate than preceding theories by Isaac Newton; but Newton's theories are still taught in 
universities, and remain useful to physicists. Likewise, neoclassical economics is a good foundation, on which more complicated theories can be built. It is to be hoped that economics will continue to be improved by adding insights from psychology and other disciplines. By including behavioural economics ideas, current economic models can be made better.

\section{References}

Ackert, L., Church, B., \& Jayarman, N. (2011). Is there a link between money illusion and Homeowners' Expectations of Housing Prices? Real Estate Economics, 39(2), 251-75. http://dx.doi.org/10.1111/j.1540-6229.2010.00295.x

Akerlof, G., \& Shiller, R. (2009). Animal Spirits: How Human Psychology drives the Economy and Why it matters for Global Capitalism (2nd ed.). Princeton University Press.

Arthur, W. B. (1991). Designing Economic Agents that Act like Human Agents: A Behavioral approach to Bounded Rationality. American Economic Review, 81(2), 353-9.

Arthur, W. B. (1993). On designing Economic Agents that act like Human Agents. Journal of Evolutionary Economics, 3(1), 1-22. http://dx.doi.org/10.1007/BF01199986

Bhattacharya, U., Galpin, N., Ray, R., \& Yu, X. (2009). The role of the media in the internet IPO bubble. Journal of Financial and Quantitative Analysis, 44, 657-82. http://dx.doi.org/10.1017/S0022109009990056

Bokhari, S., \& Geltner, D. (2011). Loss Aversion and Anchoring in Commercial Real Estate Pricing: Empirical Evidence and Price Index Implications. Real Estate Economics, 39(4), 635-70. http://dx.doi.org/10.1111/j.1540-6229.2011.00308.x

Bouelhouwer, P. (2011). Neo-Classical Economic Theory on Housing Markets and Behavioural Sciences: Ally or Opponent? Housing Theory and Society, 28(3), 276-80. http://dx.doi.org/10.1080/14036096.2011.599173

Brocker, M., \& Hanes, C. (2014). The 1920s American Real Estate Boom and the Downturn of the Great Depression: Evidence from City Cross-Sections. In E. N. White, K. Snowden, \& P. Fishback (Eds.), Housing and Mortgage Markets in Historical Perspective (pp. 161-201). University of Chicago Press: Chicago.

Case, K., \& Shiller, R. (1989). Forecasting Prices and Excess Returns in the Housing Market. AREUEA Journal, 18(3), 253-73. http://dx.doi.org/10.1111/1540-6229.00521

Case, K., \& Shiller, R. (2003). Is there a bubble in the Housing Market? Brookings Papers on Economic Activity, 2(1), 299-362. http://dx.doi.org/10.1353/eca.2004.0004

Cho, M. (1996). House Price Dynamics: A Survey of Theoretical and Empirical Issues. Journal of Housing Research, 7(2), 145-72.

Clark, G., Durán-Fernández, R., \& Strauss, K. (2009). Being in the Market: the UK house price bubble and the intended structure of individual pension investment portfolios. Journal of Economic Geography, 10(3), 331-59. http://dx.doi.org/10.1093/jeg/lbp034 
Conlisk, J. (1996). 'Why Bounded Rationality? Journal of Economic Literature, 34(2), 669-700.

Daniel, K., Hirschleifer, D., \&Subrahmanyam, A. (1998). Investor Psychology and Security Market Under and Over Reactions. Journal of Finance, 53(6), 1839-85. http://dx.doi.org/10.1111/0022-1082.00077

Dellavigna, S. (2009). Psychology and Economics: Evidence from the Field. Journal of Economic Literature, 47(2), 315-72. http://dx.doi.org/10.1257/jel.47.2.315

DeWeaver, M. A., \& Shannon, R. (2010). Waning vigilance and the disposition effect: Evidence from Thailand on individual investor decision making. Journal of Socio-Economics, 39(1), 18-23. http://dx.doi.org/10.1016/j.socec.2009.08.001

Diaz, J., \& Black, R. (1996). The use of Information versus asking price in the real estate property negotiation process. Journal of Property Research, 28(1), 287-97. http://dx.doi.org/10.1080/095999196368808

Diba, B. T., \& Grossman, H. I. (1988). Explosive Rational Bubbles in Stock Prices? American Economic Review, 78(3), 520-30.

Diba, B., \& Grossman, H. (1987). On the inception of Rational Bubbles. Quarterly Journal of Economics, 102(3), 697-700. http://dx.doi.org/10.2307/1884225

Earl, P. (2005). Economics and Psychology in the Twenty First Century. Cambridge Journal of Economics, 29(6), 909-26. http://dx.doi.org/10.1093/cje/bei077

Engelhardt, G. (2003). Nominal Loss Aversion, Housing Equity Constraints and Household Mobility: Evidence from the United States. Journal of Urban Economics, 53(1), 171-95. http://dx.doi.org/10.1016/S0094-1190(02)00511-9

Fudenburg, D. (2006). Advancing Beyond Advances in Behavioural Economics. Journal of Economic Literature, 44(1), 694-711. http://dx.doi.org/10.1257/jel.44.3.694

Genesove, D., \& Mayer, C. (2001). Loss Aversion and Seller Behaviour: Evidence from the Housing Market. Quarterly Journal of Economics, 116(4), 1233-60. http://dx.doi.org/10.1162/003355301753265561

Haigh, M., \& List, J. (2005). Do Professional Traders Exhibit Myopic Loss Aversion? An Experimental Analysis. Journal of Finance, 60(1), 523-34. http://dx.doi.org/10.1111/j.1540-6261.2005.00737.x

Hong, H. (2007). Behavioural Finance: An Introduction. European Financial Management, 13(3), 389-93. http://dx.doi.org/10.1111/j.1468-036X.2007.00365.x

Iroham, C. O., Ogunba, O. A., \& Oloyede, S. A. (2014). Effect of Principal Heuristics on Accuracy of Property Valuation in Nigeria. Journal of land and Rural Studies, 2(1), 89-111. http://dx.doi.org/10.1177/2321024913515104 
Jones, A., Geilenkeuser, T., Helbrecht, I., \& Quilgars, D. (2012). Demographic Change and Retirement Planning: Comparing Households' Views on the Role of Housing Equity in Germany and the UK. International Journal of Housing Policy, 12(1), 27-45. http://dx.doi.org/10.1080/14616718.2012.651299

Kahneman, D., \& Tversky, A. (1979). Prospect Theory: An analysis of decision under risk. Econometrica, 47(2), 263-92. http://dx.doi.org/10.2307/1914185

Kahneman, D., Knetsch, J., \& Thaler, R. (1990). Experimental Tests of the Endowment Effect and the Coase Theorem. Journal of Political Economy, 98(6), 1325-47. http://dx.doi.org/10.1086/261737

Levin, E., \& Wright, R. (1997). Speculation in the Housing Market? Urban Studies, 34(9), 1419-37. http://dx.doi.org/10.1080/0042098975493

Madsen, J. (2012). A Behavioural Model of House Prices. Journal of Economic Behaviour and Organisation, 82(1), 21-38. http://dx.doi.org/10.1016/j.jebo.2011.12.010

Marsh, A., \& Gibb, K. (2011). Uncertainty, Expectations and Behavioural Aspects of Housing Market Choices. Housing, Theory and Society, 28(3), 215-35. http://dx.doi.org/10.1080/14036096.2011.599182

McGreal, S., McCord, M., \& McIlhatton, D. (2011). The Northern Ireland Housing Market and Interconnections with the UK and Irish Housing Markets. Housing Finance International, 26(1), 28-34.

Meen, G. (1996). Ten Propositions in the UK Housing Macroeconomics: An overview of the 1980s and early 1990s. Urban Studies, 33(3), 425-44. http://dx.doi.org/10.1080/00420989650011843

Miles, D. (2004). The impact of interest rates and the housing market on the UK economy. Economic Outlook, 28(2), 10-8. http://dx.doi.org/10.1111/j.1468-0319.2004.00418.x

Minsky, H. P. (1977). The Financial Instability Hypothesis. Working Paper 74, The Jerome Levy Economics Institute of Bard College, 1-10.

Morone, A., \& Samanidou, E. (2008). A Simple note of herd behaviour. Journal of Evolutionary Economics, 18(5), 639-46. http://dx.doi.org/10.1007/s00191-007-0072-6

Muellbauer, J., \& Murphy, A. (1997). Booms and Busts in the UK Housing Market. Economic Journal, 107(445), 1701-27. http://dx.doi.org/10.1111/j.1468-0297.1997.tb00076.x

Muellbauer, J., \& Murphy, A. (2008). Housing Markets and the Economy: The assessment. Oxford Review of Economic Policy, 24(1), 1-33. http://dx.doi.org/10.1093/oxrep/grn011

Nakagawa, R., Oiwa, H., \& Takeda, F. (2012). The economic impact of herd behaviour in the Japanese loan market. Pacific-Basin Finance Journal, 20(1), 600-13. http://dx.doi.org/10.1016/j.pacfin.2012.01.002 
Niemietz, K. (2012). Planning Reform and Housing Costs: Why the coalition failed and what it means. Economic Affairs, 32(3), 70-7. http://dx.doi.org/10.1111/j.1468-0270.2012.02177.x

Northcraft, G., \& Neale, M. (1987). Experts, Amateurs and Real Estate: An Anchoring-and-Adjustment Perspective on Property Pricing Decisions. Organisational Behaviour and Human Decision Processes, 39 39(1), http://dx.doi.org/10.1016/0749-5978(87)90046-X

Odean, T. (1994). Are investors reluctant to realise their losses? Journal of Finance, 53(5), 1775-98. http://dx.doi.org/10.1111/0022-1082.00072

Paraschiv, C., \& Chenavaz, R. (2011). Sellers' and Buyers’ Reference Point Dynamics in the Housing Market. Housing Studies, 26(3), 329-52. http://dx.doi.org/10.1080/02673037.2011.542095

Pompian, M. (2012). Behavioral Finance and Wealth Management: How to Build Optimal Portfolios That Account for Investor Biases (3rd ed.). Hoboken, NJ: John and Wiley Sons.

Scheikman, J., \& Xong, W. (2003). Overconfidence and Speculative Bubbles. Journal of Political Economy, 111(6), 1183-219. http://dx.doi.org/10.1086/378531

Scherbina, A., \& Schlusche, B. (2012). Asset Bubbles: An Application of Residential Real Estate. European Financial Management, 18(3), 464-91. http://dx.doi.org/10.1111/j.1468-036X.2012.00647.x

Shiller, R. J. (1996). Speculative booms and crashes. In F. Capie \& G. E. Wood (Eds.), Monetary Economics in the 1990s (pp. 58-74). Macmillan: London.

Shiller, R. J. (2002). Bubbles, Human Judgement and Expert Opinion. Financial Analysts Journal, 58(3), 18-26. http://dx.doi.org/10.2469/faj.v58.n3.2535

Shiller, R. J. (2005). Irrational Exuberance (2nd ed.). Princeton: Princeton University Press.

Smith, A. (1759). Theory of Moral Sentiments (6th ed.). London: A. Millar.

Smith, M. H., \& Smith, G. (2006). Bubble, Bubble, Where's the Housing Bubble? Brookings Papers on Economic Activity, 1(1), 1-66. http://dx.doi.org/10.1353/eca.2006.0019

Smith, S. (2011a). Home Price Dynamics: a Behavioural Economy? Housing, Theory and Society, 28(3), 236-261. http://dx.doi.org/10.1080/14036096.2011.599179

Smith, S. (2011b). Housing Economics: The Heterodox Experiment. Housing, Theory and Society, 28(3), 300-4. http://dx.doi.org/10.1080/14036096.2011.599180

Stephens, M. (2012). Tackling Housing Market volatility in the UK Part 1: Long and Short Term Volatility. International Journal of Housing Policy, 12(3), 367-80. http://dx.doi.org/10.1080/14616718.2012.709674

Stephens, M., \& Quilgars, D. (2008). Sub-Prime Mortgage lending in the UK. European Journal of Housing Policy, 8(2), 197-215. http://dx.doi.org/10.1080/14616710802037458 


\section{IIMacrothink}

Business and Management Horizons

ISSN 2326-0297

2014, Vol. 2, No. 2

Stiglitz, J. (1990). Symposium of Bubbles. Journal of Economic Perspectives, 4(2), 13-8. http://dx.doi.org/10.1257/jep.4.2.13

Stiglitz, J. (2010). Freefall: Free Markets and the Sinking of the Global Economy (2nd ed.). London: Penguin Books.

Tsai, C., Chen, M. C., \& Ma, T. (2010). Modelling house price volatility in the UK by Switching Arch Models. Applied Economics, 42(9), 1145-53. http://dx.doi.org/10.1080/00036840701721133

Tversky, A., \& Kahneman, D. (1974). Judgement under Uncertainty: Heuristics and Biases. Science, 185(4157), 1124-31. http://dx.doi.org/10.1126/science.185.4157.1124

Watkins, C., \& McMaster, R. (2011). The Behavioural Turn in Housing Economics: Reflections on the Theoretical and Operational Challenges. Housing, Theory and Society, 28(3), 281-7. http://dx.doi.org/10.1080/14036096.2011.599177

Whitehead, C., \& Williams, P. (2011). Cause and Consequences? Exploring the Shape and Direction of the Housing System in the UK Post the Financial Crisis. Housing Studies, 26(8), 1157-69. http://dx.doi.org/10.1080/02673037.2011.618974

Whittle, R. (2013a). A behavioural consideration of the new auto enrolment pension policy. paper given at SPARC Conference 'theory, practice, impact'. Manchester UK: June 2013.

Whittle, R. (2013b). Bank Lending and the UK Housing Market. [Online] Available: http://www.business.mmu.ac.uk/eomics/?p=51 (August 24, 2014).

\section{Copyright Disclaimer}

Copyright for this article is retained by the authors, with first publication rights granted to the journal.

This is an open-access article distributed under the terms and conditions of the Creative Commons Attribution license (http://creativecommons.org/licenses/by/3.0/). 